\title{
The Effects of Human Resources Development on Financial Performance of Organisations
}

\author{
James Adetunji Odumeru ${ }^{1} \&$ Dr. Oladele Ayodeji Ilesanmi ${ }^{2}$
}

${ }^{1}$ Lecturer, Department of Banking \& Finance, Osun State College of Technology, Esa Oke, Nigeria

${ }^{2}$ Lecturer, Department of Business Administration, Osun State University, Esa Oke, Nigeria

\begin{abstract}
Contemporary organisation invests huge resources on a regular basis on Human Resources Development (HRD) initiatives because of the age long belief that this will enhance efficiency and effectiveness. But sadly, these expectations often go unfulfilled. This study empirically tests the effect of HRD on financial performance with employee competence and organisational commitment acting as mediating mechanisms. A total of 84 copies of a questionnaire that was distributed to and received from bank workers of two of Nigeria's leading banks: First Bank of Nigeria Plc and Zenith Bank Plc to elicit relevant data on employee participation in and perceived benefits of HRD, commitment $\mathcal{E}$ competence and financial performance were analysed using Cronbach's Coefficient Alpha and multiple regression analysis. Results show a significant relationship between employee participation in HRD including perceived benefits of HRD and organisational commitment and employee competence. The study also shows a significant relationship between competence $\mathcal{E}$ commitment and financial performance. Thus organisation should focus attention on delivering consistent HRD initiatives relevant to the need of employees and focused on addressing identified Skills, Knowledge and Abilities (KSA) gaps for a continuous financial performance improvement
\end{abstract}

Keywords: Human Resources Development, Training and Development, Employee Competence, Commitment, Financial Performance, Strategic Human Resources Management JEL Classification Code: M120

\section{INTRODUCTION}

Tn today's increasingly competitive business environ$\boldsymbol{I}_{\text {ment, organisations keep evolving ways of ensuring }}$ their continued survival and improving organisational performance on a sustained basis. Effective Human Resources Management (HRM) provides a means, through which an organisation attracts, retain, develop, motivate and adequately compensate employees for a sustained growth and increased competitiveness. One important aspect of HRM is Human Resources Development. Human Resources Development (HRD) is a framework for the expansion of human capital within an organisation through the development of both the organisation and the individual to achieve performance improvement. It is the integrated use of training, organisational and career improvement effort to improve individual, group and organisational effectiveness [1]. HRD is concerned with the provision of learning, development and training opportunities in order to improve individual, team and organisational performance [2].

\section{LiteRATURE REVIEW}

HRD is the process of developing and/or unleashing human expertise through organisational and personnel training and development for the purpose of improving performance at the organisational, process and individu- al/group level [3]. The bottom line of every HRD effort is to improve performance [4]. HRD programmes are, by definition, designed and implemented to improve employee capability to perform effectively and meet performance expectations [5]. Several scholars have asserted a positive relationship between HRD and organisational performance [6], [7], [8]. Swanson [4] posited that HRD affects positively the three levels of performance: organisation, process and individual. Human Capital theorists believe that firms should protect their core competencies through investment in training and development [9]. Tracey et al [10] believes that employee Knowledge, Skills, and Abilities (KSA) and motivation are the reasons for the HRD and performance relationship. This position was also supported by Barlett [11]. In a survey of 337 registered nurses across 5 hospitals and using the social exchange theory as framework, Barlett discovered that perceived access to training, social support for training, motivation to learn, and perceived benefits of training are positively related to organisational commitment.

After an extensive survey of literature on studies into the link between Human Resources Management and organisational performance covering the last twenty years, Guest [12] concluded that 'we are still in no position to assert with any confidence that good Human Resources Management (including HRD) has an impact on organisa-

19 | P a g e 
tion performance'. The relationship between HRD activities and performance at the firm level is still unclear in literature [11], [13]. Combs et al [14] identified three mediating mechanisms between Human Resources Management and performance: increasing employees KSA, motivating and empowering them to act. Despite these efforts by scholars, empirical efforts linking HRD and performance is still lacking in literature [14].

Several attempts have been made by scholars to determine the relationship between human resources practices and organisational performance. Often called High Performance Work Practices (HPWP), these include: employee recruitment and selection, training and development, employee participation, employee incentives and flexible work arrangement [15]. Using 92 studies in a metaanalysis, Combs et al [14] used varying sets of HR practices ranging from 2 to 13 . They discovered that HPWP is a strong predictor of organisational performance. However, the study showed that the impact of specific practices on performance is unclear, further justifying the need for rigorous empirical study of the effects of specific HR practices (one of which is HRD) of organisational performance. It is anticipated that this study will fill this gap.

The attempt at linking HRD and performance of organisations has led to the development of a branch of HRD; Strategic Human Resources Development (SHRD) [16]. Strategic HRD involves introducing, eliminating, modifying, directing and guiding processes in such a way that all individuals and teams are equipped with the skills, knowledge and competencies they require to undertake current and future tasks required by the organisation. Strategic HRD takes a broad and long-term view about how HRD policies and practices can support the achievement of business strategies [17]. Strategic HRD is aimed at enhancing resource capabilities in accordance with the belief that human capital of an organisation is a major source of competitive advantage [2]. In the crisis context where organisations tend to experience turmoil and multilevel changes, SHRD can provide a useful framework for leadership in designing HRD interventions that will ultimately contribute to the successful outcome of crisis planning and management [18]. Garavan et al [16] opined that SHRD promotes practices that enhance the strategic performance of employees and organisations. SHRD also emphasised proactive change in management which helps organisations survive in an increasingly complex, unstable, competitive, and global environment [19]. Wang J et al argued that by adopting performance and learningbased HRD interventions and collaborating with key stakeholders, HRD professionals can play a critical part in preparing the organisation for crisis events. However,

Copyright (C) 2013, Asian Business Consortium | ABR none of these researchers provided any clear model connecting HRD to performance.

An exception to this can be found in the work of YoungSung and Choi [20]. In a study of 207 manufacturing companies located in South Korea, they discovered that financial investment and managerial support for HRD show positive effects on employee commitment but not on competence. Perceived benefits of HRD were also discovered to enhance both employee competence and commitment, whereas the amount of participation in HRD is not a meaningful predictor of those employee outcomes. Using a series of structural equation models, the study also confirmed that HRD practices improve employee competence and commitment that have direct effects on operational performance of the organisation, which ultimately shapes its financial performance.

\section{Statement of the Problem}

The age long belief that HRD positively influences organisational outcomes and ultimately organisational performance perhaps explains the reason for heavy investment in training and development initiatives by contemporary organisations [21], [11], [22], [23], [24], [7], [25]. It is estimated that American companies spend US\$134 billion annually on employee training and development activities alone [26]. Unfortunately, these heavy investments in HRD initiatives do not always translate into improved individual and organisational performance [27]. Also direct empirical study of HRD- performance relationship is rare in literature, especially at the firm level. Most studies had focused on training effectiveness and learning transfer systems [28]. Many research efforts have established the linking employee related processes as mediating mechanisms between HR practices and performance, empirical study at the organisation level is still lacking [14]. Given the prevailing scepticism regarding the contribution of training to objective firm-level performance ([11], [13]), providing systematic models and empirical evidence regarding the HRD-performance link is imperative.

\section{Objectives of the Study}

This study will model the relationship between HRD and organisational performance. Scholars have identified three main mediating mechanisms between HR practices and organisational performance: Knowledge, Skills and Ability (KSA), employee empowerment and employee motivation [10], [14]. This study will determine the relationship between HRD practices and organisational performance with KSA, employee empowerment and motivation acting as mediating mechanisms. The framework for this study was drawn from the work of Young-Sung \& Choi [20]: the effects of employee participation and perceived benefits of 
HRD on financial performance with organisational commitment and employee competence acting as mediating mechanism.

\section{HYPOTHESES}

The following hypotheses will be tested in this research (see fig 1):

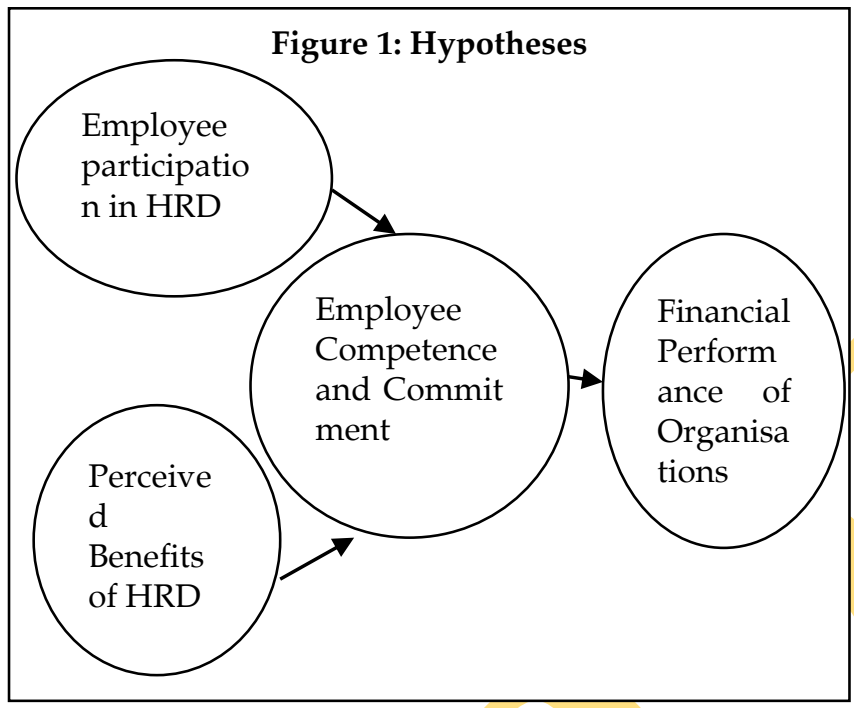

H1: Employee Participation in HRD and Perceived benefits of HRD positively influences employee competence and commitment

Employee participation in HRD is described as the degree to which employees are exposed to training and development activities measured in qualitative terms [20]. Perceived benefits of HRD are the degree to which employees perceive HRD to be task-relevant and beneficial [20]. Commitment is the level of attachment felt toward the organisation in which one is employed [11]. A committed employee is one who will stay with the organisation through thick and thin, attends work regularly, puts in a full day (and maybe more), protects company assets, and who shares company goals [29]. Competence on the other hand, is the capability of employees to perform effectively and to meet performance expectations [5].

H2: $\quad$ Employee competence and commitment positively determines financial performance.

\section{ReSEARCh Methodology}

A survey research design was adopted for this study. One hundred and twenty copies of a questionnaire were distributed to members of staff of two of Nigeria's leading banks: First Bank of Nigeria Plc and Zenith Bank Plc to elicit relevant data in the Lagos area between June and December, 2012. Purposive sampling technique was used in selecting these two banks because they are the first and second biggest banks in Nigeria in terms of customer, deposit and asset base As this research is explorative, no specific sampling technique was used in the selection members of staff of these two banks. Out of this figure, 84 returned copies were found to be usable representing a $70 \%$ response rate. The questionnaire was designed using the 5-point Likert scale. Cronbach's alpha was used to test for consistency of research instruments. Multiple regression analysis was used to analyse data and test the hypotheses.

\section{Results AND Discussion}

The table below shows result of Cronbach's Alpha

Table 1: Result of Cronbach's Alpha Test:

\begin{tabular}{|l|c|c|}
\hline Construct & $\begin{array}{c}\text { Cronbach's } \\
\text { Alpha }\end{array}$ & No. Of Items \\
\hline $\begin{array}{l}\text { Employee Participa- } \\
\text { tion in HRD }\end{array}$ & 0.79 & 5 \\
\hline $\begin{array}{l}\text { Perceived Benefits of } \\
\text { HRD }\end{array}$ & 0.77 & 6 \\
\hline $\begin{array}{l}\text { Competence and } \\
\text { Commitment }\end{array}$ & 0.81 & 7 \\
\hline $\begin{array}{l}\text { Financial Perfor- } \\
\text { mance }\end{array}$ & 0.93 & 7 \\
\hline
\end{tabular}

From the table above, the Cronbach's alpha test result range from 0.77 to 0.93 showing acceptable degree of reliability of test instruments [30].

Table 2 shows the results of multiple regression analysis of the relationship between employee participation in HRD and perceived benefit of HRD with organisational commitment and employee competence. From the table, the model explains $63 \%$ of the relationship between the dependent (commitment and competence) and independent variables (employee participation in HRD and perceived benefits of HRD.

Table 2: Model Summary

\begin{tabular}{|l|c|c|c|c|}
\hline Model & $\mathrm{R}$ & $\mathrm{R}^{2}$ & $\begin{array}{c}\text { Adj. } \\
\mathrm{R}^{2}\end{array}$ & Std. Error of Est \\
\hline 1 & .793 & .63 & .57 & .342 \\
\hline
\end{tabular}

Predictors: (Constant), Employee Participation in HRD, Perceived Benefits of HRD. Dependent Variable: Commitment and Competence

Table 3 below shows the ANOVA report of the general significance of the model. As $p$ is less than 0.05 , the model is significant. Thus, the combination of the variables significantly predicts the dependent variable $(\mathrm{F}=154.021 ; \mathrm{p}<$ 0.05). 
Table 3: ANOVA Report

\begin{tabular}{|l|l|r|r|r|r|l|}
\hline $\begin{array}{l}\text { Mod } \\
\text { el }\end{array}$ & & \multicolumn{1}{|c|}{$\begin{array}{c}\text { Sum of } \\
\text { Squares }\end{array}$} & df & $\begin{array}{c}\text { Mean } \\
\text { Square }\end{array}$ & \multicolumn{1}{c|}{ F } & \multicolumn{1}{c|}{ Sig. } \\
\hline 1 & $\begin{array}{l}\text { Regres- } \\
\text { sion }\end{array}$ & 103.475 & 5 & 22.40 & $\begin{array}{r}154 . \\
02\end{array}$ & $.000(a)$ \\
\hline & $\begin{array}{l}\text { Resid- } \\
\text { ual }\end{array}$ & 61.56 & 79 & 0.226 & & \\
\hline & Total & 165.04 & 84 & & & \\
\hline
\end{tabular}

Predictors: (Constant), Employee Participation in HRD,

Perceived Benefits of HRD Dependent Variable: Commit-

ment and Competence
Table 4 give the result of the relationship between dependent and independent variables. The table shows a positive significant relationship $(\mathrm{p}<0.05)$ between the dependent and independent variables. This means that employee participation and perceived benefits of HRD significantly determines employee commitment and competence, confirming the position of several researchers as shown by the positive coefficients of all independent variables [11], [13], [31], [7], [8].

Table 4: Coefficients

\begin{tabular}{|l|l|c|c|c|c|c|}
\hline Model & & \multicolumn{2}{|c|}{ Unstandardised Coefficients } & & T & Sig. \\
\hline & & B & Std. Error & Beta & & \\
\hline 1 & (Constant) & .223 & .217 & & .625 & .023 \\
\hline & Employee Participation in HRD & 0.51 & .132 & 2.3 & 1.635 & .011 \\
\hline & Perceived Benefits of HRD & 0.28 & .011 & 1.6 & 2.865 & .031 \\
\hline & Commitment and Competence & 0.23 & .056 & 1.6 & 3.789 & .025 \\
\hline
\end{tabular}

Predictors: (Constant), Employee Participation in HRD, Perceived Benefits of HRD. Dependent Variable: Commitment and Competence

Table 5 shows the relationship between employee competence and organisational commitment on financial performance of organisations. The table shows a $\mathrm{R}^{2}$ of 0.67 meaning that $67 \%$ of the relationship if described in the model.

Table 5 Model Summary

\begin{tabular}{|c|c|c|c|c|}
\hline Model & R & R Square & $\begin{array}{c}\text { Adjusted } \\
\text { R Square }\end{array}$ & $\begin{array}{c}\text { Std. Error } \\
\text { of Estimate }\end{array}$ \\
\hline 1 & .821 & .67 & .629 & .775 \\
\hline
\end{tabular}

Predictors: (Constant), Commitment and Competence Dependent Variable: Financial Performance

Table 6 shows the ANOVA report of the general significance of the model. As $\mathrm{p}$ is less than 0.05 , the model is significant. Thus, the combination of the variables significantly predicts the dependent variable $(F=439.531 ; \mathrm{p}<0.05)$

Table 6: ANOVA

\begin{tabular}{|l|l|c|c|c|c|c|}
\hline Model & & $\begin{array}{c}\text { Sums of } \\
\text { Square }\end{array}$ & DF & $\begin{array}{c}\text { Mean } \\
\text { Square }\end{array}$ & F & Sig. \\
\hline $\mathbf{1}$ & $\begin{array}{l}\text { Regre } \\
\text { Ssion }\end{array}$ & 113.512 & 5 & 105.351 & 439.573 & .006 \\
\hline & $\begin{array}{l}\text { Resid } \\
\text { ual }\end{array}$ & 98.529 & 79 & .59 & & \\
\hline & Total & 212.041 & 84 & & & \\
\hline
\end{tabular}

Predictors: (Constant), Commitment and Competence Dependent Variable: Financial Performance
Table 7 shows the estimates of coefficients of the independent variable. The table shows a positive relationship between independent variable and the dependent variable. Thus, with a coefficient of 0.097 , organisational commitment and employee competence does determine the financial performance of organisations. This also confirms the position of Swanson [3], [5], Katou [7], Bartlett [11], Denaley \& Huselid [31] and Young Sung and Choi [20] amongst others.

Table 7: Coefficients

\begin{tabular}{|l|l|c|c|c|c|c|}
\hline Model & & \multicolumn{3}{|c|}{$\begin{array}{l}\text { Unstandardised } \\
\text { Coefficient }\end{array}$} & \multicolumn{3}{|c|}{$\begin{array}{l}\text { Standardised } \\
\text { Coefficient }\end{array}$} \\
\hline 1 & $\mathrm{~B}$ & $\begin{array}{c}\text { Std. } \\
\text { Error }\end{array}$ & Beta & $\mathrm{t}$ & Sig. \\
\cline { 2 - 7 } & & 1.136 & .151 & & 4.97 & .00 \\
\hline & $\begin{array}{l}\text { Commitment } \\
\text { (Cond Compe- } \\
\text { tence }\end{array}$ & .097 & .223 & .023 & 6.11 & .02 \\
\hline
\end{tabular}

Predictors: (Constant), Commitment and Competence Dependent Variable: Financial Performance

From the analyses above table 8 show results of the hypotheses test. 
Table 8: Summary of Hypotheses Test Results

\begin{tabular}{|l|l|c|}
\hline H1 & \multicolumn{1}{|c|}{ Hypotheses } & Result \\
\hline $\begin{array}{l}\text { Employee Participation in HRD and } \\
\text { Perceived benefits of HRD positive- } \\
\text { ly influences employee competence } \\
\text { and commitment }\end{array}$ & Accepted \\
\hline H2 & $\begin{array}{l}\text { Employee competence and com- } \\
\text { mitment positively determines fi- } \\
\text { nancial performance }\end{array}$ & Accepted \\
\hline
\end{tabular}

\section{CONCLUSION}

This study has shown organisational commitment and employee competence are significantly determined by employee participation in HRD and perceived benefits of HRD. Also, this research has shown that financial performances of organisations depend on several factors some of which include commitment of workers to the organisation and employee competence. Thus for an improved financial performance, organisations must engage in HRD initiatives on a regular and consistent basis, all of which should be focused at making employees more effective and efficient in carrying out their duties. This study is also a confirmation of the importance of carrying out a systematic process of determining the training needs of employees on a continuous basis and effectively filling identified KSA gaps for the achievement of the organisational goal of improving financial performance.

\section{REFERENCES}

[1] Kelly D. (2001). Dual Perceptions of HRD: Issues for Policy: SME's, Other Constituencies, and the Contested Definitions of Human Resource Development, http://ro.uow.edu.au/artspapers/26 Viewed 8th February 2012

[2] Armstrong, M (2006) A Handbook of Human Resources Management (16th ed.), London: Kogan Page

[3] Swanson, R.A (1999) HRD Theory; Real or Imagines Human Resources Development International 2(1) 2 - 5

[4] Swanson, R. A. (1995). Human resource development: Performance is the key. Human Resource Development Quarterly, 6 (2), 207-313.

[5] Schwoerer, C. E., May, D. R., Hollensbe, E. C. \& Mencl, J. (2005). General and specific selfefficacy in the context of a training intervention to enhance performance expectancy. Human Resource Development Quarterly, 16, 111-129

[6] Garavan, T. N., Costine, P., \& Heraty, N. (1995). The emergence of strategic human resource development. Journal of European Industrial Training, 19(10), 4-10.

[7] Katou, A. A. (2009). The impact of human resource development on organisational performance: Test of a causal model. Journal of Behavioural \& Applied Management, 10, 335-356.

[8] Macky, K., \& Boxall, P. (2007). The relationship between highperformance work practices and employee attitudes: An investigation of additive and interaction effects. International Journal of Human Resource Management, 18, 537-567

[9] Lepak, D. P., \& Snell, S. A. (1999). The human resource architecture: Toward a theory of human resource capital allocation and development. Academy of Management Review, 24, 31-49.

[10] Tracey, J. B., Hankins, T. R., Tannenbaum, S., \& Mathieu, J. E. (2001). The influence of individual characteristics and the work environment on varying levels of training outcomes. Human Re- source Development Quarterly, 12, 5-23.

[11] Bartlett, K. R. (2001). The relationship between training and organizational commitment: A study in the health care field. Human Resource Development Quarterly, 12, 335-352.

[12] Guest, D.E (2010) Human resource management and performance: still searching for some answers http://www.americanstaffing.net/members/pdf/Staffing and CS $\underline{\mathrm{R} \text { Businessa }}$ se.pdf Viewed 6th March 2001

[13] Torraco, R.J. (1999). Advancing our understanding of performance improvement. In R.J. Torraco (Ed.), Performance improvement theory and practice. Baton Rouge, LA: Academy of Human Resource Development.

[14] Combs, J., Liu, Y., Hall, S., \& Kitchen, D. (2006). How much do high-performance work practices matter? A metaanalysis of their effects on organizational performance. Personnel Psychology, 59, 501-528.

[15] Lopez, S. P., Peon, J. M. M. \& Ordas, C. J. V. (2005). Human resource practices, organizational learning and business performance. Human Resource Development International, 8, 147-164.

[16] Garavan, T. N. (2007). A strategic perspective on human resource development. Advances in Developing Human Resources, 9:11-30.

[17] Walton. J (1999) Strategic Human Resources Development. Harlow: Financial Times/Prentice-Hall

[18] Wang J, Hutchins, H.M and Garavan, T.N (2009) Exploring the Strategic Role of Human Resource Development in Organizational Crisis Management Human Resource Development Review, 8;22 http://hrd.sagepub.com/cgi/content/abstract/8/1/22

[19] Grieves, J. (2003). Strategic human resource development. Thousand Oaks, CA: Sage.

[20] Young Sung, S \& Choi, J (2011) The Effects of Human Resource Development on Operational and Financial Performance of Manufacturing Companies: A Large-Scale, Longitudinal Analysis. Institute for Research on Labour and Employment: IRLE Working Papers.

[21] Analoui, F. (ed.) (1999) Effective human resource development: a challenge for developing countries, Ashgate, Aldershot, Hants, England

[22] Bates, R., \& Chen, H. C. (2004). Human resource development value orientations: A construct validation study. Human Resource Development International, 7, 351-370.

[23] Delahaye, B.L. (2005) Human resource development: adult learning and knowledge management, Queensland, Wiley Milton

[24] Clardy, A. (2008). The strategic role of human resource development in managing core competencies. Human Resource Development International, 11, 183-197.

[25] Woodall, J. (2001). HRDI special issue: defining HRD. Human Resource Development International, 4(3), 287.

[26] Paradise, A., \& Patel, L. (2009). 2009 State of the industry report. Alexandria, VA: American Society for Training and Development. [27] Gubbins, C., Garavan, T. N., Hogan, C., \& Woodlock, M. (2006). Enhancing the role of the HRD function: The case of a health services organisation. Irish Journal of Management, 171-206.

[28] Holton, E. F., Bates, R. A., \& Ruona, W.E.A. (2000). Development of a generalized learning transfer system inventory. Human Resource Development Quarterly, 11, 333-360.

[29] Meyer, J. P., \& Allen, N. J. (1997). Commitment in the workplace: Theory, research, and application. Thousand Oaks, CA: Sage p. 3

[30] Nunnally, J.C. (1978). Psychometric theory (2nd Edition). New York: McGraw-Hill.p. 153

[31] Delaney, J. T. \& Huselid, M. A. (1996). The impact of human resource management practices on perceptions of organizational performance. Academy of Management Journal, 39, 949-969. 